\title{
FATAL EVOLUTION OF
} SYSTEMIC LUPUS ERYTHEMATOSUS ASSOCIATED WITH CROHN'S DISEASE

\author{
Júlio M. Fonseca CHEBLI*, Pedro Duarte GABURRI*, Aécio Flávio Meirelles de SOUZA*, \\ Kátia Valéria Bastos DIAS**, Karla Oliveira CIMINO**, \\ Roberto José de CARVALHO-FILHO** e Fernando de Azevedo LUCCA**.
}

ABSTRACT - The authors describe the case of a young Brazilian woman who was treated of ileocolonic Crohn's disease sparing rectum, as confirmed by colonoscopy and histopathological examination. After a 4-year course of sulfasalazine treatment, she presented with skin facial lesions in vespertilio, fever, arthralgias and high titers of anti-ANA and LE cells. A sulfasalazine-induced lupus syndrome was diagnosed, because after sulfasalazine withdrawal and a short course of prednisone, the clinical symptoms disappeared and the laboratory tests returned to normal. Mesalazine 3 g/day was started and the patient remained well for the next 3 years, when she was again admitted with fever, weakness, arthralgias, diplopy, strabismus and hypoaesthesia in both hands and feet, microhematuria, haematic casts, hypocomplementemia and high titers of autoimmune antibodies. A diagnosis of associated systemic lupus erythematosus was made. Although a pulsotherapy with methylprednisolone was started, no improvement was noticed. A cyclophosphamide trial was tried and again no positive results occurred. The patient evolved to severe clinical manifestations of general vasculitis affecting the central and peripheral nervous system and lungs, having a fatal evolution after 2 weeks. Although uncommon, the association of both disease may occur, and the authors call attention to this possibility, making a brief review of literature.

HEADINGS - Crohn disease. Lupus erythematosus, systemic.

\section{INTRODUCTION}

Crohn's disease (CD) and systemic lupus erythematosus (SLE) have been described in a rare association ${ }^{(3)}$. Both disease have ethiopathogenesis not well known, but the more accepted theory for explanation is based in the interaction of environmental agents and immunological responses in a host genetically susceptible ${ }^{(4)}$. Sometimes the differentiation of intestinal lesions of CD from SLE is not easy. Gastrointestinal symptoms, laboratory studies, and radiographic findings may appear very similar in both diseases. However, the association of both diseases in a same patient it is not common. We report a patient, who developed a SLE with fatal evolution after 7 years of treatment for ileocolonic CD.

\footnotetext{
Division of Gastroenterology, Department of Medicine, Juiz de Fora University, School of Medicine, Juiz de Fora, MG, Brazil.

* Professor of Gastroenterology, Juiz de Fora University, School of Medicine, Juiz de Fora, MG, Brazil.

** Fellowship of Division of Gastroenterology, Department of Medicine, Juiz de Fora University, School of Medicine.

Address of correspondence: Dr. Pedro Duarte Gaburri - Rua São Sebastião, 1050/301 - 36015-410 - Juiz de Fora, MG, Brazil. e-mail: pgaburri@artnet.com.br
} 


\section{CASE REPORT}

A 24-year old Brazilian woman presented, in March 1992, with diarrhea, weight loss and abdominal pain. She had perineal and vaginal fistulae. A colonoscopy showed longitudinal scattered ulcers and erosions from ileum to descending colon. The hystopathological examination of samples of ileum and colonic mucosa demonstrated cryptitis and noncaseating granulomas. She was considered to have $\mathrm{CD}$ and sulfasalazine $3 \mathrm{~g}$ /day plus metronidazol $15 \mathrm{mg} / \mathrm{kg} /$ day were started. A clinical remission was achieved with healing of fistulae, gain of weight and relief of abdominal pain. After 6 months only sulfasalazine was being employed. She felt well for 4 years. In April 1996 she developed a "lupus-like syndrome", with skin facial lesions in "vespertilio", arthralgias and fever. High titers of autoimmune antibodies (anti-ANA) and LE cells were demonstrated in laboratory researches. She was considered to have a sulfasalazineinduced lupus syndrome and mesalazine $1.6 \mathrm{~g}$ /day was introduced in treatment after sulfasalazine withdrawal. A complete remission of all clinical and laboratory manifestations was observed and the patient became well for the next 3 years. She was admitted again in February 1999 , with perineal fistula, fever $\left(39{ }^{\circ} \mathrm{C}\right)$, arthralgias, weakness, strabismus, and hipoaestesia in the feet and both hands. The laboratory tests showed hypocomplementemia, and high titers of anti-ANA (1:320) and anti-Ro (SS-A) antibody positive, while the anti-histone antibody was negative. Urinalysis demonstrated proteinuria, microhaematuria and haematic casts. The hipoaestesia progressed to anesthesia and paraparesia of upper and lower limbs. The study of cranium and medullae through a CT scan and a MNR did not show any abnormalities. The liquor was clear with a normal protein concentration and cell count, and negative bacterioscopy analysis and culture. The above findings are in according with the American College of Rheumathology criteria for the diagnosis of $\operatorname{SLE}^{(10)}$.

A pulsotherapy with methylprednisolone was started. No signs of improvement were noticed and a cyclophosphamide trial was tried without any response. She became tetraplegic. A severe respiratory failure occurred in the 8th day and an assisted ventilatory support was introduced. No improvement was observed and she died on the 15 th day.

\section{DISCUSSION}

SLE is a multisystemic autoimmune disease with protean clinical presentations as a result of widespread inflammation and immune complex deposition. During evolution of SLE, gastrointestinal symptoms occur in approximately $50 \%$ of patients ${ }^{(5)}$. Virtually any gastrointestinal tissue can be involved, most often as a result of SLE vasculopathy.

Although it remains unclear whether $\mathrm{CD}$ is autoimmune in nature, perinuclear staining antineuthrophil cytoplasmic antibodies ( $p$ ANCA), known to be associated with vasculitis and tissue injury by activating leukocytes, occur near $15 \%$ of the cases, while remission of the disease, in the presence of HIV-infection and exacerbation, after treatment with interleukin-2, have been reported ${ }^{(6,9)}$.

Several case reports have indicated that differentiation of $\mathrm{CD}$ from SLE may be difficult. Gastrointestinal symptoms, laboratory studies, and radiographic findings may have similar features in both diseases $^{(1)}$. Moreover, the SLE syndrome has been described in patients with CD after sulfasalazine ${ }^{(2)}$ as well as mesalazine treatment ${ }^{(11)}$. Curiously, acute leukocytoclastic vasculitis of skin has been described in $\mathrm{CD}$ with the same characteristics of autoimmune diseases ${ }^{(12)}$. However, coexistence of SLE and CD has been rarely described ${ }^{(3,7,8)}$. In all these clinical situations the correct diagnosis has important treatment and prognostic implications. In our case, the biopsy specimens from the ileal and colonic mucosa showed cryptitis and non-caseating granuloma with no ischemic changes or vasculitis. After 7-years of well-controlled CD with medical treatment, the patient developed complex systemic manifestations, with hypocomplementemia, high titers of anti-ANA and anti-Ro (SS-A) antibody positive. Proteinuria, microhaematuria and haematic casts were found in urinalysis. These findings are in according with SLE diagnosis. The anti-histone antibody negative makes the hypothesis of drug-induced lupus syndrome improbable ${ }^{(11)}$. Based on these facts, we believe that our patient could accurately be diagnosed as having idiophatic SLE with CD.

In conclusion, although some of the systemic complications of these diseases may overlap, both diseases may occur as primary disorders. Coexistence of SLE in patients with inflammatory bowel diseases, should be considered when complex extraintestinal manifestations are present, especially when autoimmune-antibodies are detected. 
Chebli JMF, Gaburri PD, Souza AFM de, Dias KVB, Cimino KO, Carvalho-Filho RJ de, Lucca F de A. Evolução fatal de lupus eritematoso associado à doença de Crohn. Arq Gastroenterol 2000;37(4):224-226.

RESUMO - Descrição do caso de uma mulher jovem, brasileira, que foi tratada de doença de Crohn acometendo íleo e cólon, poupando o reto, e confirmada por colonoscopia e estudo histopatológico. Após 4 anos de tratamento com sulfasalazina, apresentou lesões faciais em vespertilio, febre, artralgia e altos títulos de anticorpo anti-nuclear e células LE. Uma síndrome lúpica induzida pela sulfasalazina foi diagnosticada, porque após a retirada desta e um curto período de administração de prednisona, os sintomas clínicos desapareceram e os testes laboratoriais retornaram ao normal. Mesalazina $3 \mathrm{~g} /$ dia foi iniciada e a paciente manteve-se bem pelos próximos 3 anos, quando foi novamente admitida com febre, adinamia, artralgias, diplopia, estrabismo e hipoestesia em ambas as mãos e pés, microhematuria, cilindros hemáticos, hipocomplementemia e altos títulos de anticorpos auto-imunes. Diagnóstico de lupus eritematoso sistêmico foi realizado. Embora uma pulsoterapia com metilpredinisolona tenha sido iniciada, nenhuma melhora foi observada. Um ciclo com ciclofosfamida foi tentado e novamente nenhum resultado positivo foi alcançado. A paciente apresentou quadro de manifestações clínicas graves de vasculite generalizada, afetando o sistema nervoso central e periférico e os pulmões, evoluindo para o óbito em duas semanas. Embora incomum, a associação entre as duas doenças pode ocorrer e é destacada esta possibilidade, com uma breve revisão da literatura.

DESCRITORES - Doença de Crohn. Lupus eritematoso sistêmico.

\section{REFERENCES}

1. Buchman AL, Wilcox CM. Crohn's disease masquerading as systemic lupus erythemathosus. South Med J 1995;88:1081.

2. Carr-Locke DL. Sulfasalazine-induced lupus syndrome in a patient with Crohn's disease. Am J Gastroenterol 1982;77:614.

3. Constans J, Bernard PH, Bakhach S, Prion F, Quinton A, Conri C. Crohn disease and systemic lupus erythematosus, a rare association. Presse Med 1993;22:1193.

4. Greenstein AJ. Extraintestinal manifestation of Crohn's disease and ulcerative disease in 700 patients. Medicine 1976;55:401.

5. Hoffman B, Katz WA. The gastrointestinal manifestations of systemic lupus erythematosus: a review of the literature. Semin Arthritis Rheum 1980;9:23.

6. James SP. Remission of Crohn's disease after human immunodeficiency virus infection. Gastroenterology 1988;95:1667.

7. Johnson DA, Diehl AM, Finkelman FD, Cattau EL Jr. Crohn's disease and systemic lupus erythematosus. Am J Gastroenterol 1985;11:869.
8. Nishida Y, Murase K, Ashida R, Sasaki O, Ozono Y, Mizuta Y, Takeshima F, Makiyama K, Kohno S. Familial Crohn's disease with systemic lupus erythematosus. Am J Gastroenterol 1998;93:2599.

9. Sparano JA, Brandt LJ, Dutcher JP, Dubois JS, Atkins MB. Symptomatic exacerbation of Crohn's disease after treatment with high-dose interleukin-2. Ann Intern Med 1993;118:617.

10. Tan EM, Cohen AS, Fries JF, Masi AT, McShane DJ, Rothfield NF, Schaller JG, Talal N, Winchester RJ. The 1982 revised criteria for the classification of systemic lupus erithematosus. Arthritis Rheum 1982;25:1271.

11. Timsit MA, Anglicheau D, Liote F, Marteau P, Dryll A. Mesalazine-induced lupus. Rev Rheum Engl Ed 1997;64:586.

12. Zlatanic J, Fleisher M, Sasson M, Kim P, Korelitz BI. Crohn's disease and acute leukocytoclastic vasculitis of skin. Am J Gastroenterol 1996;91:2410.

Recebido para publicação em 17/8/1999. Aprovado para publicação em 21/9/1999. 